\title{
The Fair Trial Rationale for Excluding Wrongfully Obtained Evidence
}

\author{
Hock Lai Ho
}

\begin{abstract}
Many rationales have been offered for the judicial power to exclude wrongfully obtained evidence. Each rationale shapes the scope of such power differently. This chapter selects for examination three legal systems in which the avowed rationale is to uphold the fairness of the trial. It explores the premises underlying, and the limitations of adopting, the fair trial rationale in these three jurisdictions. An examination of the case-law suggests that there is room for greater critical engagement on the meaning of a fair trial, clearer articulation of how fairness is undermined by allowing reliance on wrongfully obtained evidence, and deeper reflection on whether the fair trial rationale provides a sufficiently broad basis for exclusion.
\end{abstract}

\section{Introduction}

In most jurisdictions, the judge conducting a criminal trial has the power to exclude evidence obtained by unlawful or otherwise wrongful means. Legal systems have adopted different rationales for exclusion, resulting in variations in the scope of the exclusionary power. ${ }^{1}$ This chapter engages in a study of three systems of law in which the avowed basis for exclusion is to uphold the fairness of the trial. Part II examines the jurisprudence of the European Court of Human Rights (ECtHR) on the right to a fair trial contained in article 6 of the European Convention on Human Rights ('the Convention'). Part III considers the common law and statutory rules

\footnotetext{
${ }^{1}$ See Ho, 2019; Turner/Weigend, 2019.
}

I am grateful to Sabine Gless and her team, Laura Macula, Thomas Richter and Peng Xinyun, for being wonderful hosts of the workshop at which I presented a version of this paper and to the participants for their valuable comments.

\section{H. L. Ho $(\bowtie)$}

Faculty of Law, National University of Singapore (NUS), Singapore, Singapore

e-mail: lawhohl@nus.edu.sg

S. Gless and T. Richter (eds.), Do Exclusionary Rules Ensure a Fair Trial?

Ius Gentium: Comparative Perspectives on Law and Justice 74,

https://doi.org/10.1007/978-3-030-12520-2_9 
relating to wrongfully obtained evidence in England. Part IV explores the admissibility and discretion to exclude such evidence under Singapore law.

These three case studies provide the contexts for probing the premises underlying, and the implications of adopting, the fair trial rationale for exclusion. This rationale raises a number of issues that deserve fuller attention by the courts. What is the point or purpose a trial? How should fairness be conceived? When would the admission of wrongfully obtained evidence undermine the fairness of the trial? The answers to these questions are contestable and bear on the scope of the exclusionary power. There is room for greater conceptual clarity in the law.

\section{European Convention on Human Rights}

\subsection{Introduction}

Member states of the Council of Europe are parties to the Convention. The Convention does not contain any provision that deals directly with the exclusion of wrongfully obtained evidence. However, article 6 of the Convention guarantees, as its title states, 'the right to a fair trial'. The ECtHR, which is an international court established to hear applications alleging violations of the Convention, has repeatedly held that article 6 'does not lay down any rules on the admissibility of evidence as such, which is therefore primarily a matter for regulation under national law. ${ }^{, 2}$ In determining whether there has been a violation of article 6, the ECtHR will consider 'whether the proceedings as a whole, including the way in which the evidence was obtained, were fair.' ${ }^{3}$ The use or admission of unlawfully obtained evidence in a particular case may render the proceedings unfair as a whole. ${ }^{4}$ It is in this indirect way - in the context of deciding whether, in the case at hand, there has been a breach of the right to a fair trial in article 6-that the issue of unlawfully obtained evidence has received attention by the ECtHR. ${ }^{5}$

\footnotetext{
${ }^{2}$ Schenk v. Switzerland (1991) 13 EHRR 242 at [46].

${ }^{3}$ Jalloh v. Germany (2007) 44 EHRR 32 at [95]. See also X v. Belgium, Application no. 8876/80, 16 Oct 1980: while art. 6(1) guarantee the right to a fair trial, it does not prescribe rules of evidence, in particular, rules of admissibility. For the purposes of art. 6(1), what has to be determined is "whether evidence for and against the accused has been presented in such a manner and the proceedings in general have been conducted in such a way that he has had a fair trial'.

${ }^{4}$ See Summers, 2007 at 130, noting that the ECtHR has often emphasized the 'difficulties of separating the trial from the proceedings as a whole'. The fair trial requirements in art. 6 is not confined to the trial proceeding; they apply also to the investigative stage: see, e.g., Aleksandr Zaichenko v. Russia, Application no. 39660/02, 18 February 2010 at [42].

${ }^{5}$ Jackson/Summers, 2012 at 163. See also Ramanauskas v. Lithuania (2010) 51 EHRR 11 at [52] ('In this context, the Court's task is not to determine whether certain items of evidence were obtained unlawfully, but rather to examine whether such "unlawfulness" resulted in the infringement of another right protected by the Convention.') Pattenden, 2009 at 61 (arguing, in the context of evidence obtained by torture or inhuman or degrading treatment, that the exclusionary rule should be read into Art. 3 itself and exclusion should not be based on Art. 6).
} 
The method used in obtaining the evidence may be unlawful in a number of ways. It may have been in breach of domestic law or a Convention right other than article 6 (examples are given below) or a right implied in article 6 itself (such as the right of silence or privilege against self-incrimination). ${ }^{6}$ The breach of a Convention right, or other law, that is committed in procuring evidence during criminal investigation is conceptually distinct from the breach of the right to a fair trial in article 6(1); the latter is occasioned by a separate event, namely, the use of the evidence at the trial. As Lord Hoffmann explained in the context of evidence obtained by torture in Montgomery v. H. M. Advocate ${ }^{7}$ :

Of course events before the trial may create the conditions for an unfair determination of the charge. For example, an accused who is convicted on evidence obtained from him by torture has not had a fair trial. But the breach of article 6(1) lies not in the use of torture (which is, separately, a breach of article 3) but in the reception of the evidence by the court for the purposes of determining the charge. If the evidence had been rejected, there would still have been a breach of article 3 but no breach of article 6(1).

\subsection{Approach to exclusion under article 6(1) of the Convention}

It is understandable why the ECtHR has repeatedly insisted that each member state is generally free to devise its own rules on the admissibility of evidence. This is in accord with the principle of subsidiarity and respect for the sovereignty of member states and with the reluctance of the ECtHR to act as a 'fourth instance' appeal. ${ }^{8}$ At the same time, the right to a fair trial in article 6-being a human right-sets the basic and universally applicable standards that must be met for a trial in any member state to be considered fair. ${ }^{9}$ In reality, and contrary to repeated disavowals by the ECtHR, article 6 does in effect require member states to adopt certain basic or minimal rules on admissibility (or, to use a broader term, 'useability') of evidence in the legal determination of guilt.

For instance, torture is prohibited by article 3, as is 'inhuman and degrading treatment'. In Jalloh v. Germany, the ECtHR took the view that 'incriminating evidence-whether in the form of a confession or real evidence-obtained as a result of ...[torture] - should never be relied on as proof of the victim's guilt, irrespective of its probative value. ${ }^{10}$. This principle was not applicable on the facts

\footnotetext{
${ }^{6}$ See, e.g., Saunders v. UK (1997) 23 EHRR 313; Allan v. UK (2003) 36 EHRR 12 at [51] ('Whether the right to silence is undermined to such an extent as to give rise to a violation of Art. 6 of the Convention depends on all the circumstances of the individual case').

${ }^{7}(2003) 1$ AC 641 at 649.

${ }^{8}$ Emmerson et al., 2012 at [2]-[114], [13]-[68].

${ }^{9} \mathrm{Ho}, 2012 \mathrm{a}$.

${ }^{10}$ Jalloh v. Germany (2007) 44 EHRR 32 at [105].
} 
in Jalloh v. Germany as the treatment of the accused was found not to amount to torture. But the principle has been applied in later cases. ${ }^{11}$ In effect, article 6(1) read with article 3 requires all member states to adopt the categorical rule that evidence obtained by torture is inadmissible and cannot be used as proof of guilt in legal proceedings. The same categorical approach applies also to evidence of a confession or statement obtained from the accused by inhuman or degrading treatment that falls short of torture. ${ }^{12}$

However, the ECtHR has not adopted a similar categorical rule of exclusion for other types of unlawfully obtained evidence such as real evidence obtained by inhuman or degrading treatment, ${ }^{13}$ evidence derived from evidence obtained by torture or inhuman or degrading treatment ('fruits of the poisonous tree'), ${ }^{14}$ and evidence obtained by means that contravene the right of privacy in article $8 .{ }^{15}$ Use or admission of such evidence will not automatically render the trial unfair. The Strasbourg court will assess the fairness of the proceedings considered as a whole and engage in a balancing of countervailing considerations. In this connection, a number of factors have been treated as relevant in the overall assessment. They include $^{16}$ :

- the seriousness of the offence with which the accused is charged ('the weight of the public interest in the investigation and punishment of the offence in issue ${ }^{17}$ );

_ 'whether the rights of the defence rights have been respected" ${ }^{18}$;

- the opportunities afforded the accused to challenge the authenticity and oppose the use or admissibility of the evidence and whether the domestic court had the power to exclude the evidence if it were minded to do so $^{19}$;

- 'whether the circumstances in which [the evidence] was obtained cast doubts on its reliability or accuracy ${ }^{20}$; and

\footnotetext{
${ }^{11}$ Harutyunyan v. Armenia (2009) 49 EHRR 9 at [63], [66]; Levinta v. Moldova, Application no. 17332/03, 16 December 2008.

${ }^{12}$ Gafgen v. Germany (2011) 52 EHRR 1 at [166], [173]; see also Pattenden, 2010 at 366, citing other earlier cases.

${ }^{13}$ Jalloh v. Germany (2007) 44 EHRR 32 at [107]: the 'general question whether the use of evidence obtained by an act qualified as inhuman and degrading treatment automatically renders the trial unfair can be left open'. It was held, taking into account the particular circumstances of the case, that use of the evidence of drugs obtained by forced administration of emetics rendered the trial unfair (ibid. at [108]).

${ }^{14}$ See Gafgen v. Germany (2011) 52 EHRR 1 at [147], [178] (it seems that there is a strong presumption in favour of exclusion).

${ }^{15}$ See, e.g., Khan v. UK (2001) 31 EHRR 45; PG and JH v. UK [2002] Criminal Law Review 308; Allan v. UK (2003) 36 EHRR 12.

${ }^{16}$ See Choo, 2013 at 338.

${ }^{17}$ Jalloh v. Germany (2007) 44 EHRR 32 at [97].

${ }^{18}$ Gafgen v. Germany (2011) 52 EHRR 1 at [164].

${ }^{19}$ Emmerson et al., 2012 at [13]-[50].

${ }^{20}$ Gafgen v. Germany (2011) 52 EHRR 1 at [164].
} 
- the role played by the wrongfully obtained evidence in supporting the guilty verdict (that is, whether the conviction was based on the evidence, ${ }^{21}$ and if it was, whether it was the sole or decisive evidence or whether the guilty verdict was supported by other evidence).

To reiterate, under Strasbourg jurisprudence, the question raised by unlawfully obtained evidence is not whether the domestic court should have excluded it as such; it is whether, in the light of all relevant factors, the use or admission of the evidence in the domestic proceedings rendered it unfair as a whole and hence in contravention of article 6 . How is this determination made? In particular, how can unlawfulness in the method used by investigators in obtaining evidence prior to the trial impact on the fairness of the trial $?^{22}$ And how are the factors mentioned above relevant to the fairness of the trial? It is difficult to extract clear and coherent principles from the Strasbourg jurisprudence. $^{23}$

The relevance of the factors listed above and the adoption of a balancing approach (as opposed to categorical exclusion) have drawn criticisms from academics $^{24}$ and dissenting judges of the ECtHR. ${ }^{25}$ One criticism that has been made is that a trial can never be fair if the accused was convicted on evidence obtained in violation of a Convention right. As Judge Spielmann pointed out in dissent in Bykov v. Russia, ${ }^{26}$ 'the fairness required by article 6 of the Convention also entails a requirement of lawfulness. Fairness presupposes respect for lawfulness and thus also, a fortiori, respect for the rights guaranteed by the Convention'. ${ }^{27}$ Now, one

\footnotetext{
${ }^{21}$ Ibid. at [164].

${ }^{22}$ Jackson/Summers, 2012 at 184 ('the ECtHR has been slow to elaborate on the relationship between the regulation of the investigation or pre-trial phase and the fairness of the trial').

${ }^{23}$ See, e.g., Jackson/Summers, 2012 at 194 (noting that the ECtHR 'has not yet developed a deliberate and reasoned approach to determining why or under which circumstances evidence which has been improperly obtained during the pre-trial investigative phase will impact on the rights of the defence at trial'); Goss, 2014 at 58-62 (noting that the ECtHR's approach to the evidence law is marked by incoherence).

${ }^{24}$ See, e.g., Ashworth, 2012. On balancing of rights and interests in the criminal process generally, see, e.g., Maher, 1984 and Cottingham, 1984.

${ }^{25}$ See, e.g., the dissenting judgments of Judge Bratza in Jalloh v. Germany (2007) 44 EHRR 32 at [0]-[19] ('the fairness of the judicial proceeding is in my view irreparably damaged in any case where evidence is admitted which has been obtained by the authorities of the State concerned in violation of the prohibition of Article 3'); Judge Loucaides in Khan v. UK (2001) 31 EHRR 45 at [0]-[I4] ('I cannot accept that a trial can be "fair", as required by Article 6, if a person's guilt for any offence is established through evidence obtained in breach of the human rights guaranteed by the Convention'); and Judge Tulkens in $P G$ and $J H$ v. $U K$, Application no. 44787/98, 25 September 2001 at [1] ('I do not think that a trial can be described as "fair" where evidence obtained in breach of a fundamental right guaranteed by the Convention has been admitted during the trial').

${ }^{26}$ Judge Spielmann in Bykov v. Russia, Application no. 4378/02, 10 March 2009 at [7], joined by Judges Rozakis, Tulkens, Casadevall and Mijovic.

${ }^{27}$ Ashworth, 2012 at 159, reads this as an argument based on the rule of law and as a version of the integrity principle.
} 
can accept that the fairness of a trial cannot only be about the reliability of the evidence on which the court acts and the accuracy of the verdict that it reaches. But it is not self-evident that 'fairness presupposes respect for lawfulness' and that a trial can never be fair if the accused is convicted on evidence obtained in violation of a Convention right. This further claim is in need of a supporting argument.

\subsection{Possible Theoretical Bases}

One argument that could be made is that it is unfair to allow the state to profit from its own wrongdoing. ${ }^{28}$ In the situation where evidence has been obtained through a wrongful act on the part of an agent of the state (namely, the police), to allow the state (through the prosecution) to use the evidence against the accused is to allow the state to derive an advantage over the accused that it ought not to have in their adversarial contest. There are potential difficulties with this theory. Supporters of the so-called separation thesis would emphasize that it was the police who had committed the wrong in obtaining the evidence, and, insofar as there was no complicity by the prosecution in this wrong, the prosecution is arguably not benefiting from its own wrong in using the evidence at the trial. One way of getting around this difficulty is to treat the police and prosecution not as separate agents but as members of the collective agent that is the state. ${ }^{29}$ If they are members of the same collective agent, the wrong of one qua member of the collective agent may be attributed to the other qua member of the same collective agent. This may dissolve the difficulty posed by the separation thesis to the no-profit principle.

A second possible argument has been advanced by Summers ${ }^{30}$ together with Jackson. ${ }^{31}$ As they explain, 'unlike the traditional legitimacy theories,... the focus [of their argument] is not on the moral reprehensibility of the state authorities' conduct, but rather on the effect of the conduct on the ability of the accused (and the defence) to present its case. ${ }^{32}$ The contention, in gist, is that the right to a fair trial is infringed by allowing the prosecution to use unlawfully obtained evidence at the trial where and insofar as this circumvents and irremediably undermines certain basic rights which the defence has at the trial, which rights are essential to uphold if the trial is to be considered fair. ${ }^{33}$ In particular, for the trial to be considered fair, it

\footnotetext{
${ }^{28}$ See, e.g., Duff/Farmer/Marshall/Tadros, 2007 at 107-8; Chau, 2016.

${ }^{29} \mathrm{See}$ Ho, 2016a.

${ }^{30}$ Summers, 2007.

${ }^{31}$ Jackson/Summers, 2012 chapter 6 and especially at 169, 177. See also Jackson, 2009.

${ }^{32}$ Jackson/Summers, 2012 at 195.

${ }^{33}$ For a similar argument in Canadian jurisprudence, see Paciocco/Stuesser, 2015 at 406: earlier decisions of the Supreme Court of Canada adopted the reasoning that "since a "fair trial" demands the Crown prove its case without calling the accused as a witness, a trial would become unfair if the Crown could indirectly co-opt the accused as a witness by presenting out-of-court statements obtained from the accused in violation of the [Canadian Charter of Rights and Freedoms]'.
} 
is essential to uphold the general right of the accused person to have 'the opportunity to challenge the evidence levelled against [him or her] by the prosecution and to present [his or her] own evidence in adversarial proceedings, that is to say assisted by defence counsel in proceedings adjudicated by an independent and impartial judge. ${ }^{34}$ The admission of unlawfully obtained evidence may circumvent and irremediably undermine this general 'fair trial' right. Consider the situation where the accused was denied the assistance of a lawyer during police interrogation. The accused has a right to present his or her evidence assisted by a lawyer at the trial. ${ }^{35}$ This right may be 'irretrievably prejudiced' if incriminating statements obtained from the accused during the interrogation and without prior access to legal advice are used-as pre-constituted or ready-made evidence - against him or her at the trial. ${ }^{36}$

However, this line of argument has not succeeded before the ECtHR for all breaches of Convention rights. As Jackson and Summers noted, the ECtHR displays a trial-centric bias. For instance, case-law on article 8 (right to privacy) violations 'suggests that provided that the applicant had the opportunity to raise the alleged impropriety at trial and that the trial court considered the applicant's argument and had the discretion to decide not to use the evidence, the fairness of the trial will not be compromised by the decision to make use of the evidence in convicting the accused. ${ }^{37}$ There is reluctance by the ECtHR to take a direct and more interventionistic stance in regulating the pre-trial investigative processes. ${ }^{38}$ As such, the exclusionary rule, based as it is on the ECtHR's interpretation of the right to a fair trial, is of limited efficacy in regulating pre-trial evidence-gathering by law enforcement agencies. ${ }^{39}$

It is unclear how far this line of argument may be pushed. The resistance to regulating evidence-gathering at the investigation stage by the same set of norms as those that govern the trial stem in large part from the fear that this may hamper criminal investigation. For instance, it does not seem feasible to insist that police interrogation be conducted openly in the way trials are conducted openly. Is it any more feasible to insist that no statement obtained during any closed-door police interrogation should ever be admitted as evidence at the trial? ${ }^{40}$

\footnotetext{
${ }^{34} \mathrm{Ibid}$. at $195-6$.

${ }^{35}$ Art. 6(3)(c).

${ }^{36}$ See Salduz v. Turkey (2008) 49 EHRR 19 at [55].

${ }^{37}$ Jackson/Summers, 2012 at 181. See, e.g., Khan v. UK (2001) 31 EHRR 45 at [38]-[40] and Allan v. UK (2003) 36 EHRR 12 at [48], ibid. at [52].

${ }^{38}$ Summers, 2007 at 163 : 'it is insufficient and inconsistent continually to emphasise the importance of the adversarial trial and yet to neglect the ways in which this can be undermined.'

${ }^{39}$ See Jackson/Summers, 2012 at 186.

${ }^{40}$ Summers, 2007 at 131 : criticizing the ECtHR for paying 'insufficient attention ... to the type of regulation which is required in the investigation phase. The reluctance of the Strasbourg authorities to insist on the application of adversarial principles during the investigation stage gives rise to some serious tensions as to the theoretical ability of the provision to set out consistent principles for regulating fair trials.... If evidence is heard and challenged solely in a non-public forum which is not supervised by an impartial judge, it must be questioned to what extent the "trial rights" in Article 6(1) can still be said to have application and meaning.'
} 


\section{England}

\subsection{Common Law Approach to Wrongfully Obtained Evidence}

At common law, the general rule is that the wrongfulness of the method by which the evidence was obtained does not affect its admissibility. In $R$ v. Leatham, ${ }^{41}$ a case before the Court of Queen's Bench, Justice Crompton famously stated: 'It doesn't matter how you get it; if you steal it even, it would be admissible.' There are exceptions to this rule. Involuntary confessions ${ }^{42}$ and evidence obtained by torture $^{43}$ are inadmissible at common law. ${ }^{44}$ The automatic exclusion of involuntary confessions has been rationalised in terms of reliability concerns, the privilege against self-incrimination and the legitimacy or integrity of the criminal process. ${ }^{45}$ Of these three rationales, the last has been identified as the main reason for the strict inadmissibility of evidence obtained by torture. ${ }^{46}$

If the evidence is inadmissible, the judge must exclude it. No discretion is involved. If the evidence is admissible, the judge conducting a criminal trial may nevertheless exclude it under certain circumstances. Arguably, some support exists in a number of pre-1979 decisions for the view that the wrongfulness of the method by which the evidence was obtained can in itself justify the exercise of this exclusionary discretion. Dicta in cases such as Kuruma v. $R .^{47}$ (a decision of the

\footnotetext{
${ }^{41}(1861) 8$ Cox CC 498. See also $R$ v. Warickshall (1738) 1 Leach 263.

${ }^{42}$ The confession must be voluntary 'in the sense that it has not been obtained ... by fear of prejudice or hope of advantage or hope of advantage, exercised or held out by a person in authority, or by oppression': Mirfield, 1997 at 76 citing principle (e) of the Judges' Rules 1964 as a convenient statement of the common law rule.

${ }^{43}$ A v. Secretary of State for the Home Department (No.2) [2006] 2 AC 221.

${ }^{44}$ In addition to these common law exceptions, a categorical rule of exclusion also applies to intercepted communications to which the Regulation of Investigatory Powers Act 2000 applies: see Emmerson et al., 2012 at 651; Choo, 2013 at 331.

${ }^{45}$ As the Privy Council put it in Lam Chi-Ming v. $R$ [1991] 2 AC 212 at 220 (decision on appeal from Hong Kong):
}

[T] he rejection of an improperly obtained confession is not dependent only upon possible unreliability but also upon the principle that a man cannot be compelled to incriminate himself and upon the importance that attaches in a civilised society to proper behaviour by the police towards those in their custody. All three of these factors have combined to produce the rule of law applicable in Hong Kong as well as in England that a confession is not admissible in evidence unless the prosecution establish that it was voluntary.

See generally Mirfield, 1997, chapter 2.

${ }^{46} A$ v. Secretary of State for the Home Department (No.2) [2006] 2 AC 221 admitting evidence obtained by torture would 'compromise the integrity of the judicial process, dishonour the administration of justice' (ibid. at 280, per Lord Hoffmann), 'shock the conscience, abuse or degrade the proceedings and involve the state in moral defilement' (ibid. at 299, per Lord Carswell).

${ }^{47}[1955]$ AC 197. 
Privy Council hearing an appeal from Kenya) and Callis v. Gunn ${ }^{48}$ (a judgment of the Queen's Bench Division of the English High Court ${ }^{49}$ suggest that the judge may exclude evidence where it was gained by 'a trick ${ }^{50}$ or by 'oppressive' means or 'by false representations, ... by threats, by bribes, anything of that sort'. ${ }^{51}$ However, in 1979, the scope of the common law discretion to exclude wrongfully gathered evidence was curtailed by the House of Lords in $R$ v. Sang. ${ }^{52}$ The House of Lords was asked to address a certified question of law on the scope of the exclusionary discretion. The following answer was given by Lord Diplock ${ }^{53}$ :

(1) A trial judge in a criminal trial has always a discretion to refuse to admit evidence if in his opinion its prejudicial effect outweighs its probative value.

(2) Save with regard to admissions and confessions and generally with regard to evidence obtained from the accused after commission of the offence, he has no discretion to refuse to admit relevant admissible evidence on the ground that it was obtained by improper or unfair means.

Although all of the other law lords expressed agreement with this answer, there were significant differences in their views. ${ }^{54}$ Of all the judgments, it is that of Lord Diplock that has had the greatest impact on later cases. ${ }^{55}$ Glossing over differences in the judgments, the general effect of Sang was to confine within relatively narrow limits the scope of the discretion to exclude evidence on the ground of its wrongful provenance.

The discretion in limb (1) in the quotation above rests on a different ground. It allows the judge to exclude evidence where its prejudicial effect outweighs its probative value in the sense that the jury is likely to attach undue weight to the evidence. ${ }^{56}$

\footnotetext{
${ }^{48}[1964] 1$ QB 495.

${ }^{49}$ Other relevant cases include Jeffrey v. Black [1978] QB 490 at 498, $R$ v. Payne [1963] 1 WLR 637 and King v. $R$ [1969] 1 AC 304.

${ }^{50}$ Kuruma v. $R$ [1955] AC 197 at 204.

${ }^{51}$ Callis v. Gunn [1964] 1 QB 495 at 502.

${ }^{52}$ [1980] AC 402.

${ }^{53} \mathrm{Ibid}$. at 437.
}

${ }^{54}$ As one commentator put it, 'no single ratio clearly emerged from the case': Sharpe, 1998 at 52. Amongst the judges, Lord Diplock and Viscount Dilhorne gave the discretion the narrowest scope. The latter judge disagreed with the dicta found in earlier cases insofar as they suggested a wide discretion and he took the view that some of the earlier cases, such as $R$ v. Payne [1963] 1 WLR 637 at 637 and Jeffrey v. Black [1978] QB 490, were wrongly decided: $R$ v. Sang [1980] AC 402 at 440-441. Lord Scarman, on the other hand, explicitly declined to reject the earlier dicta: ibid. at 456.

${ }^{55}$ Mirfield, 1997 at 118, 119.

${ }^{56}$ Scott v. $R$ [1989] 1 AC 1242 at 1256; $R$ v. Christie [1914] 1 AC 545 at 559. See also Dennis, 2017 at 93: 'Evidence is unfairly prejudicial to the accused if its use at trial would tend to lead the factfinder to convict the accused for reasons other than the proper probative value of the evidence'. This is distinguishable from 'reasoning prejudice' and 'moral prejudice' which are more relevant in the context of evidence of the accused's bad character or previous misconduct: see, ibid. at 796-8. 
The scope of the exclusionary discretion extends beyond this. ${ }^{57}$ It also allows the judge to exclude evidence where admitting it 'will put the accused at an unfair advantage or deprive him of the ability to defend himself'. ${ }^{58}$ Significantly, in all these instances, the focus is on the use of the evidence at the trial, in particular, on the impact of admitting the evidence on the reliability of the verdict or the fairness of the adversarial contest in court. The exclusion does not rest (at least, not directly) on any objection there might be to the manner in which the evidence was obtained prior to the trial. ${ }^{59}$

According to the answer given by Lord Diplock in Sang, the discretion to exclude evidence on the direct basis of its wrongful procurement is available only for the two categories of evidence stated in limb (2) above. Outside of these two categories, wrongfulness in the method of obtaining evidence does not on its own warrant its exclusion at common law. The first category consists of 'admissions and confessions'. For example, while a breach of the Judges' Rules in obtaining a confession does not make it inadmissible, the evidence may be excluded at the court's discretion. ${ }^{60}$

The second category is 'evidence obtained from the accused after commission of the offence'. ${ }^{61}$ It is unclear what this category consists of. The only authority cited by Lord Diplock for this category was $R$ v. Payne. ${ }^{62}$ There the accused was charged with drunk-driving. The police obtained his agreement to undergo a medical examination to ascertain if he was suffering from any illness or disability. This was on the understanding that he would not be examined on his fitness to drive. In breach of this agreement, the doctor gave evidence at the trial of the accused's unfitness to drive. The English Court of Criminal Appeal held that the trial judge ought to have excluded the evidence, even though it was strictly speaking admissible, and quashed the conviction. In Sang, Lord Diplock interpreted Payne as a case which was 'analogous to unfairly inducing a defendant to confess to an

\footnotetext{
${ }^{57}$ See $R$ v. Sang [1980] AC 402 at 445.

${ }^{58}$ Grant v. $R$ [2007] $1 \mathrm{AC} 1$ at [21].

${ }^{59}$ However, the manner in which evidence was obtained may cast doubt on reliability of the evidence, and this in turn may cause its probative value to be outweighed by its prejudicial effect. ${ }^{60}$ The Judges' Rules were guidelines for police officers on interviewing suspects. As the Privy Council explained in Peart v. $R$ [2006] 1 WLR 970 at [1]: 'Although classed formally as administrative directions..., they were afforded over time a higher status, and a general requirement became established that police officers had to observe them if confessions received were to be admitted in evidence. They have been replaced in England and Wales by the provisions of Code C made under the Police and Criminal Evidence Act 1984'.

${ }^{61}$ Lord Diplock confined this limb to cases where the evidence was 'tantamount to a self-incriminatory admission which was obtained from the defendant, after the offence had been committed, by means which would justify a judge in excluding an actual confession which had the like self-incriminating effect': $R v$. Sang [1980] AC 402 at 436. Other judges took broader views and were content to leave the discretion under limb (2) open-ended: Lord Salmon, ibid. at 445; Lord Fraser, ibid. at 450; Lord Scarman, ibid. at 456-7. Real and uncontroversial examples are difficult to find.

${ }^{62}$ [1963] 1 WLR 637. Similarly, see R v. Court [1962] Criminal Law Review 697.
} 
offence' and explained exclusion on the principle of the privilege against self-incrimination. ${ }^{63}$ The accused was unfairly induced to submit to a medical examination which would and did expose his guilt. In effect, he was misled into condemning himself.

On Lord Diplock's statement of the common law, the discretion to exclude improperly or unfairly obtained evidence is of limited scope. If, say, the police were to enter illegally and steal real evidence from the premises of a third party ${ }^{64}$ this alone would not permit the judge to exclude it: the evidence falls outside of the second category since it is not of a confession or admission, and the police did not get it 'from the accused'. For the discretion to be available, not only must the evidence have been obtained from the accused, it must also have been obtained 'after the commission of the crime'. Strictly speaking, this further requirement would not be satisfied where evidence was obtained during or before the commission of the crime such as 'evidence of an agent provocateur' or evidence procured 'by such means as illegal telephone tapping or bugging. ${ }^{65}$

\subsection{Fair Trial Rationale and Its Limitations}

The common law exclusionary discretion is said to stem from 'a judge's duty in a criminal trial to ensure that a defendant receives a fair trial. ${ }^{, 66}$ Taking the central purpose of the trial as the search for the truth, the accused's right to a fair trial has come to be understood primarily as the right to have the truth in the criminal charge determined in a process that is accurate and reliable, and this right is subverted where the court relies on unreliable (and, hence, 'prejudicial') evidence in ascertaining the accused's guilt. This is a narrow reading of the concept of a fair trial.

Lord Diplock drew a firm line between fairness in the method of obtaining evidence in the course of criminal investigation and fairness in using the evidence at the trial. The use of wrongfully obtained evidence at a trial does not ipso facto render the trial unfair in the narrow sense. Where the reliability of the evidence is unaffected by its wrongful provenance, the interest in a fair trial does not call for its exclusion. The only exceptions where wrongful provenance alone justifies discretionary exclusion were, according to Lord Diplock, confession and analogous evidence; and he explained these exceptions as resting of the privilege against self-incrimination.

\footnotetext{
${ }^{63} R$ v. Sang [1980] AC 402 at 435.

${ }^{64}$ For Lord Fraser, the discretion applied not only to cases where the evidence was obtained from the accused but also to cases where the evidence was obtained from premises occupied by the accused: ibid. at 452.

${ }^{65}$ Pattenden, 1990 at 266.

${ }^{66}$ Lobban v. The Queen [1995] 1 WLR 877 at 886. See also $R$ v. Sang [1980] AC 402 at 436-7, $445,450,454 ; R$ v. Christie [1914] 1 AC 545 at 559.
} 
One serious limitation of the common law exclusionary discretion, as so interpreted, is that, leaving aside confession and analogous evidence, wrongfulness in the method by which the police had procured the evidence, however objectionable the method might be, would not alone allow the judge to exclude the evidence. For Lord Diplock, it is no part of the judicial function to exclude evidence for the reason that the judge dislike - and however much the judge may dislike - the way it was obtained. ${ }^{67}$ This would appear to leave no room for the exclusionary discretion to serve any extra-epistemic purpose such as deterring the police from engaging in similar behaviour in the future or registering judicial disapproval of their conduct or protecting the integrity or legitimacy of the administration of criminal justice or upholding the rule of law.

\subsection{Position Under the Police and Criminal Evidence Act 1984 ('PACE 1984')}

Section 76(2) of PACE 1984 creates a new exclusionary rule that supplements the common law. Under this section, a confession obtained from the accused is inadmissible if it was obtained either (a) by oppression ${ }^{68}$ or (b) 'in consequence of anything said or done which was likely, in the circumstances existing at the time, to render [the confession] unreliable'. In either of these situations, 'the court shall not allow the confession to be given in evidence against him except in so far as the prosecution proves to the court beyond reasonable doubt that the confession (notwithstanding that it may be true) was not obtained as aforesaid.' Emphasising the words in italics, Dennis contends, with the backing of authorities, that this section 'is concerned with the issue of the methods used to obtain the confession (the "legitimacy" issue) and not with the issue of the whether the actual confession itself is true or false (the "reliability" issue), 69

Section 76(2) concerns admissibility as a matter of law and is restricted to confession evidence. As noted, even where the (confession or other) evidence is admissible as a matter of law, the judge presiding over a criminal trial has some discretion at common law to exclude it in limited circumstances. The common law discretion is retained under section 82(3) of the Police and Criminal Evidence Act 1984. A new statutory discretion is created under section 78 of the same Act. Section 78(1) states (italics added):

In any proceedings the court may refuse to allow evidence on which the prosecution proposes to rely to be given if it appears to the court that, having regard to all the circumstances, including the circumstances in which the evidence was obtained,

\footnotetext{
${ }^{67} R$ v. Sang [1980] AC 402 at 437.

${ }^{68}$ Section 76(8) PACE 1984 states that oppression 'includes torture, inhuman or degrading treatment, and the use of threat of violence (whether or not amounting to torture).'

${ }^{69}$ Dennis, 2017 at 239.
} 
the admission of the evidence would have such an adverse effect on the fairness of the proceedings that the court ought not to admit it.

'The precise scope of s. 78 and the extent to which it enlarges the exclusionary discretion at common law, is still not settled. ${ }^{70}$ Clarity is lacking in the drafting of the provision. One the one hand, it expressly instructs the judge, in exercising the discretion, to take into account the 'circumstances in which the evidence was obtained'. One might read this as a broadening of the common law discretion in the sense that the provision acknowledges the possibility of wrongfulness in the procurement of evidence being a sufficient ground for exclusion. ${ }^{71}$ On the other hand, the provision also requires the court to consider all other relevant circumstances and the decisive factor is whether admitting the evidence would have an 'adverse effect on the fairness of the proceedings' ${ }^{72}$ If 'proceedings' is read narrowly to mean the 'trial', the discretion would seem no wider than at common law since the crucial consideration under this section, as at common law, would then be whether the use of the evidence at the trial will render the trial unfair, ${ }^{73}$ and it is by no means obvious that "what has gone on pre-trial is capable of adversely affecting the fairness of the trial itself'. 74

\subsection{Reliability Interpretation of Fair Trial and Its Limitations}

The appellate courts have been reluctant to provide guidelines to trial judges on the exercise of the exclusionary discretion under section $78(1) .{ }^{75}$ While it is difficult to discern 'a wholly coherent approach to this very wide discretion', 76 academic commentators have observed that the courts have "wedded themselves...to the reliability principle' ${ }^{77}$ In exercising the discretion, 'evidential reliability is at the forefront of the...courts' thinking, the primary concern apparently being with

\footnotetext{
${ }^{70}$ Dennis, 2017 at 96.

${ }^{71}$ This reading was rejected by the Court of Appeal in $R$ v. Chalkley [1998] 2 Cr App R 79 at 105.

${ }^{72}$ Bingham, 2000 at 48 ('It may be that the pendulum has swung too far towards exclusion upon breaches being shown, without adequate consideration of the effect on the fairness of the proceedings which the Act requires.')

${ }^{73}$ Dennis, 2017 at 104, 97-98 (making a compelling case for a broad interpretation of the section).

${ }^{74}$ Mirfield, 1997 at 131. On how fairness of the trial might be affected, see ibid. at 131-137.

${ }^{75}$ Choo, 2013 at 341, citing $R$ v. Samuel [1988] QB 615 at 630.

${ }^{76}$ Bingham, 2000 at 47.

${ }^{77}$ Ormerod/Birch, 2004 at 779. Dennis, 2017 at 325, suggesting that the discretion is wide enough to achieve other goals.
} 
the determination of the truth rather than with upholding due process. ${ }^{, 78}$ The fact that the evidence was obtained wrongfully is not enough to warrant exclusionary discretion; admitting the evidence must be shown to undermine the 'fairness of the proceedings'. ${ }^{79}$ While the term 'proceedings' is potentially wider than 'trial', Lord Nicholls expressed the traditional view when he stated in $R$ v. Looseley $^{80}$ that "fairness of the proceedings" in section 78 is directed primarily at matters going to fairness in the actual conduct of the trial; for instance, the reliability of the evidence and the defendant's ability to test its reliability'. If the trial is considered in isolation from the pre-trial criminal process, the difficulty arises in explaining how wrongful evidence-gathering activities at the investigation stage can make the trial that occurs later unfair. ${ }^{81}$ Sometimes, the courts are prepared to construe fairness more widely; most notably, there is judicial openness to using section 78(1) to exclude evidence obtained in an entrapment. ${ }^{82}$ In $R$ v. Sultan Khan, ${ }^{83}$ Lord Nicholls stated that the approach to exclusion of wrongfully obtained evidence under article 6 of the ECHR and under section 78 of the PACE 1984 are essentially the same: both are directed at ensuring 'that those facing criminal charges receive a fair hearing'.

Founding the exclusionary discretion on a narrow conception of trial fairness, and having the reliability of the challenged evidence as the major preoccupation, will result in a restrictive - and critics would say, unduly restrictive-application of section 78. It will make the discretion narrower than an exclusionary rule that is based on the notion of integrity or legitimacy, such as a rule that requires evidence to be excluded where it would 'be detrimental to the administration of justice' (as in South Africa) ${ }^{84}$ or would 'bring the administration of justice into disrepute' (as in Canada). ${ }^{85}$ It is also narrower than an exclusionary rule that rests on broad public policy considerations (as in Australia ${ }^{86}$ ). As two authors have jointly argued ${ }^{87}$ :

\footnotetext{
${ }^{78}$ Choo, 2013 at 352 . Courts are content to restrict the focus of s. 78 on reliability concerns partly as a result of the expansion of the power to stay proceedings under the abuse of process doctrine, the latter being seen as an alternative judicial device for protecting rights in, and controlling, the criminal process: Ormerod/Birch, 2004 at 779.

${ }^{79}$ Emmerson et al., 2012 at 645.

${ }^{80} R$ v. Looseley [2001] 1 WLR 2060 at [12].

${ }^{81}$ See Mirfield, 1997 at 131 (noting the difficulty), 133-137 (discussing unusual situations in which the fairness of the trial might be affected).

${ }^{82} R$ v. Smurthwaite and Gill (1994) 98 Cr App Rep 437; $R$ v. Looseley [2001] 1 WLR 2060 at [18], [42]-[44] (Lord Hoffmann thought that a stay of proceedings was the more appropriate remedy). ${ }^{83}$ [1997] AC 558 at 583.

${ }^{84}$ Constitution of South Africa, s. 35(5).

${ }^{85}$ Canadian Charter of Rights and Freedoms, s. 24(2).

${ }^{86}$ Section 138 of the Uniform Evidence Act in Australia requires improperly or unlawfully evidence to be excluded 'unless the desirability of admitting the evidence outweighs the undesirability of admitting evidence that has been obtained in the way in which the evidence was obtained.'

${ }^{87}$ Ormerod/Birch, 2004 at 782 . According to Dennis, 2017 at 325 , the s. 78 discretion is in principle wide enough to allow exclusion to serve the other purposes mentioned above.
} 
the trial is not merely about reliably convicting the guilty and ensuring the protection of the innocent from conviction; there is an important judicial responsibility to maintain the moral integrity of the process. To date, the courts have relinquished the opportunity to use s. 78 to establish and maintain this moral legitimacy.

\section{Singapore $^{88}$}

\subsection{Introduction}

As Singapore was formerly a British colony, her law has been influenced by English common law. In Singapore, as at common law, wrongfully obtained evidence raises two separate issues. The first is the admissibility of such evidence as a matter of law. If the evidence is inadmissible as a matter of law, it must be excluded; the judge has no discretion not to do so. If the evidence is admissible as a matter of law, the party may seek to adduce it at the trial; but this does not mean that the court must admit the evidence. At this point, a second issue arises: the court may sometimes exclude wrongfully obtained evidence even though it is technically admissible. These two issues will be discussed in turn. We will consider, first, the extent to which wrongfulness in the means by which evidence was obtained affects its admissibility and, secondly, the discretion to exclude admissible evidence that has been wrongfully obtained.

\subsection{Admissibility of Wrongfully Obtained Evidence}

Evidence is rendered inadmissible by the wrongfulness of the means by which it was procured only in a small number of situations. The first set of situations involves statements obtained from the accused. As an exception to the hearsay rule, any statement made by the accused is generally admissible as evidence at his or her trial. ${ }^{89}$ However, the statement would be inadmissible under the so-called voluntariness rule if the making of the statement was caused by any inducement, threat or promise proceeding from a person in authority. ${ }^{90}$ Courts have founded this rule on the rationale of ensuring reliability of the statement ${ }^{91}$ and, alternatively, deterring 'impropriety on the part of the interrogators'. 92 Complementing the voluntariness rule is the oppression doctrine. Under this doctrine, the statement would be

\footnotetext{
${ }^{88}$ See generally Ho, 2019.

${ }^{89}$ Section 258(1), Criminal Procedure Code, chapter 68, 2012 revised edition ('CPC').

${ }^{90}$ Section 258(3), CPC.

${ }^{91}$ See, e.g., Poh Kay Keong v. PP [1995] 3 SLR(R) 887 at [42].

${ }^{92} P P$ v. Sng Siew Ngoh [1995] 3 SLR(R) 755 at [48].
} 
inadmissible if it was obtained by means that tend to sap and have in fact sapped the free will of the accused. ${ }^{93}$ It is rare to succeed in having a statement excluded under this doctrine as the threshold of oppression is pegged very high. ${ }^{94}$ While the burden is on the prosecution to prove that the statement was made voluntarily and free of oppression, ${ }^{95}$ the courts have stressed that the standard of proof must be consonant with investigative pragmatism. This attitude is reflected, for example, in judicial acknowledgement that the 'police work in difficult circumstances. If they are required to remove all doubt of influence or fear, they would never be able to achieve anything. ${ }^{96}$

Neither the voluntariness rule nor the oppression doctrine is applicable if the wrongfully obtained evidence is not in the form of a statement by the accused. Thus, they would not apply where an incriminating blood sample was obtained from the accused without complying with the legal requirement of getting his or her prior consent. ${ }^{97}$ Even if the evidence is of the form of a statement by the accused, the statement must have been obtained by the proscribed means for the voluntariness rule or the oppression doctrine to come into play. A statement taken by a police officer in flagrant disregard of the prescribed legal procedure but without any inducement, threat or promise, or oppression, ${ }^{98}$ remains admissible as a matter of law. (Whether there is discretion to exclude admissible evidence is discussed below.)

While there is no direct authority on this point, it is likely that evidence obtained by torture will be treated as inadmissible in legal proceedings under article 9(1) of the Constitution of Singapore. This provision guarantees the right not to be deprived of one's life or personal liberty 'save in accordance with law'. ${ }^{99}$ The term 'law' in this context has been interpreted to include fundamental rules of natural justice. In Yong Vui Kong v. $P P{ }^{100}$ a case involving an unsuccessful challenge to the constitutionality of caning as a form of punishment, the Court of Appeal noted in an obiter dictum that it 'would violate the fundamental rules of natural justice... to convict a person based on evidence procured by torture'. To do so would strike 'at the very heart of a fair trial.' While exclusion of evidence obtained by torture is explained with reference to the notion of a fair trial, the court did not explain how reliance on such evidence would render the trial unfair.

\footnotetext{
${ }^{93}$ Section 258(3), explanation 1, CPC.

${ }^{94} \mathrm{See}$ Ho, 2016b at 256-260.

${ }^{95}$ Panya Martmontree v. PP [1995] 2 SLR(R) 806 at [26].

${ }^{96}$ Ibid. at [29].

${ }^{97}$ See, e.g., Ajmer Singh v. PP [1985-1986] SLR(R) 1030.

${ }^{98}$ Section $258(3)$, explanation 2(e), CPC states that a statement will not be rendered inadmissible merely because it was obtained without full compliance with the prescribed procedure. Notwithstanding this, the court retains a discretion to exclude the statement where there was flagrant and serious irregularities as discussed below.

${ }^{99}$ Ong Ah Chuan v. PP [1979-1980] SLR(R) 710 at [26].

${ }^{100}$ [2015] 2 SLR 1129 at [64]. See Ho, 2019.
} 


\subsection{Discretion to Exclude Admissible Evidence to Ensure a Fair Trial}

Even where the wrongfully obtained evidence is not rendered inadmissible under any of the rules just mentioned, the court may in limited circumstances exclude the evidence at its discretion. ${ }^{101}$ The availability and scope of this discretion was clarified in the leading case of Muhammad bin Kadar v. PP. ${ }^{102}$ This case involved statements obtained by the police from an accused person in a highly irregular manner where the procedural rules set out in the Criminal Procedure Code (' $\mathrm{CPC}$ ') and internal police rules (known as Police General Orders) were deliberately flouted. No reasonable explanation for the flagrant procedural deviations was given. The Court of Appeal held, following the House of Lords' decision in $R$ v. Sang, ${ }^{103}$ that the trial judge has the discretion to exclude evidence that is more prejudicial than probative and, in the case under appeal, the trial judge should have exercised the discretion to exclude the accused's statements.

Reversing the position arguably taken in earlier case-law, ${ }^{104}$ the Court of Appeal stressed that 'courts...should refrain from excluding evidence based only on facts indicating unfairness in the way the evidence was obtained (as opposed to unfairness in the sense of contributing to a wrong outcome at trial). ${ }^{105}$ That the evidence was obtained unfairly prior to the trial cannot be used as the direct basis for exercising the discretion to exclude it at the trial. However, where the evidence was obtained in such a manner as to cast serious doubt on its reliability, its probative value would be very low; at the same time, the prejudicial effect of the evidence - in one sense of 'prejudice' — might be high. In Muhammad bin Kadar v. $P P$, there were serious doubts about the reliability of the statements given the highly suspicious manner in which the procedures were deliberately flouted. This undermined the probative value of the evidence. At the same time, the statements were prejudicial in the sense that the statements might attract more weight than they truly deserve, a risk that arises due to the 'aura of reliability' that formal statements obtained by the police tend to have. ${ }^{106}$

While exclusion serves the interest in a fair trial by ensuring the reliability of the evidence on which the court makes its findings of fact and the accuracy of those findings, other incidental benefits may also accrue at the broader or systemic level. The Court of Appeal noted that the exclusion of evidence obtained in flagrant

\footnotetext{
${ }^{101}$ The common law in this regard was held to be applicable via s. 2(2) of the Evidence Act, chapter 97, 1997 revised edition: Muhammad bin Kadar v. PP [2011] 3 SLR 1205 at [51].

${ }^{102}$ Muhammad bin Kadar v. PP [2011] 3 SLR 1205 at [68]. On the development of the law leading up to this case, see Ho, 2012b.

${ }^{103}$ [1980] AC 402.

${ }^{104}$ Cheng Swee Tiang v. PP [1964] MLJ 291, approved by the Court of Appeal in Chan Chi Pun v. $P P$ [1994] 1 SLR(R) 654 at [12].

${ }^{105} \mathrm{Ibid}$. at [68].

${ }^{106} \mathrm{Ibid}$. at [58].
} 
disregard of the governing procedure would 'remove the incentive for such non-compliance on the part of police officers' in the future and that 'a vigilant emphasis on the procedural requirements...can have a positive effect on the quality of such evidence generally. ${ }^{107}$ However, this salutary consequence is not the point or purpose of exclusion; the avowed point or purpose is to maintain a fair trial, as narrowly construed.

\subsection{Other Rationales}

Other rationales have been considered in judicial decisions. However, they have either been rejected or assigned a marginal role. In Muhammad bin Kadar v. PP, the Court of Appeal rejected the disciplinary rationale; it cautioned that 'the court should be careful to avoid basing the exercise of the exclusionary discretion primarily on a desire to discipline the wrongful behaviour of police officers'. ${ }^{108}$

In Wong Keng Leong Rayney v. Law Society of Singapore, ${ }^{109}$ Justice V. K. Rajah expressed provisional support for the judicial integrity rationale by stating, in an obiter dictum, that, if he "were unfettered by any authority, [he] would be persuaded that there will be particularly egregious instances of misconduct where the courts should reject evidence that has been procured in a manner that might be inimically repellent to the integrity of the administration of justice.' However, in the later case of Law Society of Singapore v. Tan Guat Neo Phyllis, ${ }^{110}$ the High Court, sitting as court of three judges, distanced itself from the view expressed by Justice Rajah by pointing out that the latter had expressed his views 'without the benefit of hearing arguments about the effect of the [Evidence Act] and the separation of powers'. ${ }^{11}$ It appears that the judge has since abandoned the idea of using the principle of judicial integrity to widen the scope of the exclusionary discretion. ${ }^{112}$

${ }^{107}$ Ibid. at [68].

${ }^{108}$ Ibid. at [68]. See also SM Summit Holdings Ltd v. PP [1997] 3 SLR(R) 138 at [48] ('It is not the business of the court to discipline the police').

${ }^{109}$ [2006] 4 SLR 934 at [64]. Justice Rajah referred to Ashworth, 1999 at 307 and Ashworth, 2002 at 163 .

${ }^{110}$ [2008] 2 SLR(R) 239 at [148].

${ }^{111}$ In the earlier case of SM Summit Holdings Ltd v. PP [1997] 3 SLR(R) 138 at [48], the High Court had noted that the integrity rationale is a double-edge sword: while 'the public would lose respect for the court as a dispenser of justice if it is seen to condone illegality', judicial integrity is equally undermined 'when the public perceives that factually-guilty people are getting away with serious crimes because of a trivial breach of legislation.'

${ }^{112}$ This is perhaps discernible from the later case of Lee Chez, Kee v. PP [2008] 3 SLR(R) 447 at [106] where the judge endorsed the position adopted in Law Society of Singapore v. Tan Guat Neo Phyllis [2008] 2 SLR(R) 239. According to him, the court of three judges in the latter case had 'persuasively ruled that apart from the confines of the EA, there is no residual discretion to exclude evidence which is otherwise rendered legally relevant by the EA.' 
In the civil context, the Court of Appeal has recently aired the tentative view that evidence obtained in violation of a person's rights or in an unlawful manner may justifiably be excluded in order to vindicate the rule of law. It is unclear whether the Court of Appeal would give this rationale equal force in the criminal context. According to the Court of Appeal, it 'may weigh against the court excluding the evidence' that it may deprive the prosecution of evidence needed to convict the accused. ${ }^{113}$ Priority, it seems, was accorded to the social interests in crime control.

\subsection{Evaluation}

In summary, the criminal court in Singapore has discretion to exclude wrongfully obtained evidence. This discretion is available where the potential prejudicial effect of admitting the evidence outweighs its probative value. The reasoning is that admitting overly prejudicial evidence will undermine the fairness of the trial. To the extent that the fact-finder might give the prosecution's evidence more weight than it truly deserves, it exposes the accused to an unduly high risk of a miscarriage of justice. Thus, the notion of a fair trial is construed in terms of evidential reliability and accuracy in fact-finding in the case before the court.

Implicit in this approach are certain questionable premises. One of them, which has been encountered, is the separation thesis. On this thesis, unfairness in the method of obtaining evidence is distinct from, and does not taint, the fairness of the trial at which the evidence is sought to be used. ${ }^{114}$ Another premise is the belief that exclusion of evidence as a direct response to police impropriety is tantamount to judicial activism inasmuch as it is an illegitimate judicial incursion into the executive sphere. $^{115}$

There are limitations inherent in this approach. In theory, the judge would have no discretion to exclude evidence that is incontrovertibly and highly probative (as will often be the case with real evidence), however objectionable the method used in obtaining it. ${ }^{116}$ In an entrapment where the accused was essentially caught red-handed, there is typically no dispute about the reliability of the evidence obtained in the operation. ${ }^{117}$ It has been held, reversing an approach set out in an

\footnotetext{
${ }^{113} A N B$ v. ANC [2015] 5 SLR 522 at [29]. For a critique of this case, see Ho, 2016b at 274-275.

${ }^{114}$ See, e.g., Ashworth, 2003. For a theoretical argument against the separation thesis, see Ho, 2016 a.

${ }^{115}$ See, e.g., How Poh Sun v. PP [1991] 2 SLR(R) 270 at [21]: 'It is not the province of the court to consider whether the [law enforcement officers] should have proceeded about its work in one way or the other. The court can only be concerned with the evidence before it.'

${ }^{116}$ Unless torture was applied, in which case the evidence is likely to be inadmissible as a matter of law as noted earlier.

${ }^{117}$ See Law Society of Singapore v. Tan Guat Neo Phyllis [2008] 2 SLR(R) 239 at [126] ('in the case of entrapment evidence..., by definition, the probative value of such evidence must be greater than its prejudicial value in proving the guilt of the accused').
} 
earlier case, ${ }^{118}$ that the fact that the evidence was obtained in an entrapment does not provide a basis for exercising the exclusionary discretion. ${ }^{119}$ If the concept of 'prejudice' is limited to the notion that the evidence adduced by the prosecution might be given more weight than it objectively deserves, broader interests in protecting civil liberties, ${ }^{120}$ or in upholding the rule of law ${ }^{121}$ or the legitimacy of criminal convictions, ${ }^{122}$ or in the integrity or repute of the administration of criminal justice ${ }^{123}$ would apparently have to drop out of consideration entirely.

How the demands of a 'fair trial' are construed would depend on what we understand to be point of holding a trial. On a wider view, the trial is not only about getting the facts right; it is more broadly about securing the legitimacy of the verdict. On this argument, the aim is not simply to convict criminals; the aim is to ensure that no one is convicted unless and until guilt is proved by means that are fair and just. While society has an interest in convicting persons who are guilty of crimes, it also has a profound stake in the fairness and integrity of the criminal justice system, in holding officials who are tasked with enforcing the criminal law to the law. The police, perhaps more than ordinary citizens, have the duty to respect and uphold the law. Judges should not concern themselves only with the reliability of evidence and accuracy of the verdict. More fundamentally, they should see themselves as guardians of the legitimacy of criminal convictions and the rule of law. If this is accepted, an exclusionary discretion that is founded on the concept of a 'fair trial' would have to expand its scope beyond 'prejudice' in the narrow sense.

\section{Conclusion}

The three systems of law that we have examined endorse the fair trial rationale for excluding wrongfully obtained evidence. They share the conceptual premise that exclusion turns on whether reliance on the evidence in support of a criminal conviction would render the trial unfair. Under a system of separation of powers, there is an advantage in taking this trial-centric approach. It immunizes the judiciary from any accusation of judicial activism and of exceeding its legitimate remit. Maintaining the fairness of court proceedings is manifestly a judicial responsibility and, as some judges have felt the need to stress, the exclusion of evidence is not for the purpose of disciplining the police or telling them how to do their job.

\footnotetext{
${ }^{118}$ Cheng Swee Tiang v. PP [1964] MLJ 291.

${ }^{119}$ Law Society of Singapore v. Tan Guat Neo Phyllis [2008] 2 SLR(R) 239.

${ }^{120}$ Cheng Swee Tiang v. PP [1964] MLJ 291.

${ }^{121}$ See, e.g., Ho, 2016a.

${ }^{122}$ See, e.g., Dennis, 2017 at 52-59.

${ }^{123}$ See, e.g., s. 24(2) of the Canadian Charter of Rights and Freedoms which requires the exclusion of evidence obtained in violation of a charter right or freedom if "having regard to all the circumstances, the admission of it in the proceedings would bring the administration of justice into disrepute.'
} 
The 'fair trial' rationalization faces a number of limitations. A common conception of a trial is as a fact-finding exercise. The principal aim is to ascertain the truth. There is a tendency to interpret 'fairness' purposively through the lens of reliability and accuracy. This promotes a narrow understanding of the right to a fair trial where, in the present context, it is not much more than the right to have the criminal charge determined by the court on reliable evidence and by an accurate process. On this narrow understanding of a fair trial, it is difficult to justify the exclusion of evidence that, despite its wrongful provenance, is reliable. Even the ECtHR, which frames the issue broadly as one involving the overall fairness of the trial and not merely as an evidentiary point, struggles to explain how the reception of wrongfully obtained evidence in determining the criminal charge can make the trial unfair, and the balancing approach applied by the ECtHR does not give clear guidance on when this will be the case.

Another limitation arises from viewing the trial in isolation from the criminal investigation that precedes it. On this view, the unfairness in obtaining the evidence in the course of criminal investigation and the fairness of using the evidence at the trial are separate matters. It does not follow from the fact that the evidence was obtained unfairly that it is unfair to use the evidence against the accused at the trial. As Justice Cardozo would ask: why should the criminal go free just because the constable has blundered $?^{124}$ Furthermore, any wrong committed by a law enforcement officer in getting the evidence is more appropriately addressed in a different forum or at a separate proceeding. ${ }^{125}$ These arguments beg the question by denying the criminal court any role or responsibility beyond determining the criminal charge faced by the accused. This view is contestable and rejected in some legal systems. A foray into other rationales is beyond the scope of this chapter. It has only sought to question what it means to use fair trial as the basis for excluding evidence, the implications of doing so, and the suppositions that underpin the operation of this rationale.

\section{References}

\section{Books}

Dennis, Ian, The Law of Evidence 6th edn., London 2017. [Dennis, 2017]

Duff, Antony/Lindsay Farmer/Sandra Marshall/Victor Tadros, The Trial on Trial: Towards a Normative Theory of the Criminal Trial, Oxford 2007. [Duff/Farmer/Marshall/Tadros, 2007]

Emmerson, Ben et al., Human Rights and Criminal Justice 3rd edn., London 2012. [Emmerson et al., 2012]

Goss, Ryan, Criminal Fair Trial Rights-Article 6 of the European Convention on Human Rights, Oxford 2014. [Goss, 2014]

\footnotetext{
${ }^{124}$ People v. Defore, 242 N.Y. 13, 21 (1926) Court of Appeal of New York.

${ }^{125}$ On alternative ways of safeguarding the rights of an accused person, see Gless/Macula, 2019.
} 
Jackson, John D./Sarah J. Summers, The Internationalisation of Criminal Evidence-Beyond the Common Law and Civil Law Traditions, Cambridge 2012. [Jackson/Summers, 2012]

Mirfield, Peter, Silence, Confessions and Improperly Obtained Evidence, Oxford 1997. [Mirfield, 1997]

Paciocco, David M./Lee Stuesser, The Law of Evidence 7th edn., Toronto 2015. [Paciocco/ Stuesser, 2015]

Pattenden, Rosemary, Judicial Discretion and Criminal Investigation, Oxford 1990. [Pattenden, 1990]

Sharpe, Sybil, Judicial Discretion and Criminal Investigation, London 1998. [Sharpe, 1998]

Summers, Sarah J., Fair Trials-The European Criminal Procedural Tradition and the European Court of Human Rights, Oxford 2007. [Summers, 2007]

\section{Journal Articles}

Ashworth, Andrew, 'Re-drawing the Boundaries of Entrapment' [2002] Criminal Law Review, 161-179. [Ashworth, 2002]

Ashworth, Andrew, 'What is wrong with Entrapment?' [1999] Singapore Journal of Legal Studies, 293-317. [Ashworth, 1999]

Ho, Hock Lai, "National Values on Law and Order" and the Discretion to Exclude Wrongfully Obtained Evidence' [2012] Journal of Commonwealth Criminal Law, 232-256. [Ho, 2012b]

Ho, Hock Lai, 'On the Obtaining and Admissibility of Incriminating Statements' (2016) Singapore Journal of Legal Studies, 249-276. [Ho, 2016b]

Ho, Hock Lai, 'The Criminal Trial, the Rule of Law and the Exclusion of Unlawfully Obtained Evidence' (2016) 10 Criminal Law and Philosophy, 109-131. [Ho, 2016a]

Jackson, John, 'Re-Conceptualizing the Right of Silence as an Effective Fair Trial Standard' (2009) 58 International and Comparative Law Quarterly, 835-861. [Jackson, 2009]

Ormerod, David/ Diane Birch, 'The Evolution of the Discretionary Exclusion of Evidence' [2004] Criminal Law Review, 767-788. [Ormerod/Birch, 2004]

Pattenden, Rosemary, 'Admissibility of Evidence Derived from the Interrogation of the Defendant by Methods Prohibited by Article 3-European Court of Human Rights' (2010) 14 International Journal of Evidence and Proof, 365-373. [Pattenden, 2010]

Pattenden, Rosemary, 'Evidence Obtained by Inhuman Treatment in Violation of Article 3European Court of Human Rights' (2009) 13 International Journal of Evidence and Proof, 58-61. [Pattenden, 2009]

\section{Contributions to Edited Volumes and Annotated Law}

Ashworth, Andrew 'Exploring the Integrity Principle in Evidence and Procedure', in: P. Mirfield/ R. Smith (eds.), Essays for Colin Tapper, London 2003, 107-125. [Ashworth, 2003]

Ashworth, Andrew, 'The Exclusion of Evidence Obtained by Violating a Fundamental Right: Pragmatism before Principle in the Strasbourg Jurisprudence', in: Paul Roberts/Jill Hunter (eds.), Criminal Procedure and Human Rights-Reimagining Common Law and Procedural Traditions, Oxford 2012, 145-161. [Ashworth, 2012]

Bingham, Tom, 'The Discretion of the Judge', in: Tom Bingham, The Business of JudgingSelected Essays and Speeches, Oxford 2000, 35-51. [Bingham, 2000]

Chau, Peter, 'Excluding Integrity? Revising Non-Consequentialist Justifications for Excluding Improperly Obtained Evidence in Criminal Trials', in: Jill Hunter/Paul Roberts/Simon N.M. Young/David Dixon (eds.), The Integrity of Criminal Process: From Theory into Practice, Oxford 2016, 267-279. [Chau, 2016] 
Choo, Andrew L-T, 'England and Wales: Fair Trial Analysis and the Presumed Admissibility of Physical Evidence', in: Stephen C. Thaman (ed.), Exclusionary Rules in Comparative Law, Dordrecht 2013, 331-354. [Choo, 2013]

Cottingham, John, 'The Balancing Act-Weighing Rights and Interests in the Criminal Process', in: Antony Duff/Nigel Simmonds (eds.), Philosophy and the Criminal Law, Wiesbaden 1984, 109-115. [Cottingham, 1984]

Gless, Sabine/Macula, Laura, 'Exclusionary Rules-Is it Time for Change?', in: Gless, Sabine/ Richter, Thomas (eds.), Do Exclusionary Rules Ensure a Fair Trial? A Comparative Perspective on Evidentiary Rules, Cham 2019, 349-380 [Gless/Macula, 2019]

Ho, Hock Lai, 'Criminal Justice and the Exclusion of Incriminating Statements in Singapore', in: Gless, Sabine/Richter, Thomas (eds.), Do Exclusionary Rules Ensure a Fair Trial? A Comparative Perspective on Evidentiary Rules, Cham 2019, 213-252. [Ho, 2019]

Ho, Hock Lai, 'Exclusion of Wrongfully Obtained Evidence: A Comparative Analysis', forthcoming in: Darryl Brown/Jenia I. Turner/Bettina Weißer (eds.), The Oxford Handbook of Criminal Process, Oxford, forthcoming. [Ho, forthcoming]

Ho, Hock Lai, 'The Presumption of Innocence as a Human Right', in: Roberts/Hunter (eds.), Criminal Evidence and Human Rights-Reimagining Common Law Procedural Traditions, Oxford 2012, 259-281. [Ho, 2012a]

Maher, Gerry, 'Balancing Rights and Interests in the Criminal Process', in: Antony Duff/Nigel Simmonds (eds.), Philosophy and the Criminal Law, Wiesbaden 1984, 99-108. [Maher, 1984]

Turner, Jenia I./Weigend, Thomas, 'The Purposes and Functions of Exclusionary Rules: A Comparative Overview', in: Gless, Sabine/Richter, Thomas (eds.), Do Exclusionary Rules Ensure a Fair Trial? A Comparative Perspective on Evidentiary Rules, Cham 2019, 255-282 [Turner/Weigend, 2019]

Hock Lai Ho is the Amaladass Professor of Criminal Justice at the NUS. He holds an LL.B. from NUS, a BCL from Oxford University and a Ph.D. from Cambridge University. He has published internationally in the fields of evidence, proof and aspects of the administration of criminal justice. His research ranges from doctrinal analysis of Singapore law to theoretical and comparative reflections on broader issues of the criminal trial.

Open Access This chapter is licensed under the terms of the Creative Commons Attribution 4.0 International License (http://creativecommons.org/licenses/by/4.0/http://creativecommons.org/ licenses/by/4.0/), which permits use, sharing, adaptation, distribution and reproduction in any medium or format, as long as you give appropriate credit to the original author(s) and the source, provide a link to the Creative Commons license and indicate if changes were made.

The images or other third party material in this chapter are included in the chapter's Creative Commons license, unless indicated otherwise in a credit line to the material. If material is not included in the chapter's Creative Commons license and your intended use is not permitted by statutory regulation or exceeds the permitted use, you will need to obtain permission directly from the copyright holder.

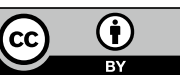

